Malikussaleh Journal of Mathematics Learning (MJML)

p-ISSN: 2620-6315 | e-ISSN: 2620-6323

Homepage: https://ojs.unimal.ac.id/mjml/index

\title{
Let your students cheat on mathematics online exams: students' perspectives
}

\author{
Erdawati Nurdin ${ }^{1 *}$, Zubaidah Amir MZ1 ${ }^{1}$, Hayatun Nufus', Deepti Thakur ${ }^{2}$, Firdous A. Shah ${ }^{3}$, Rakesh Dube ${ }^{4}, \&$ \\ Tommy Tanu Wijaya ${ }^{5}$ \\ ${ }^{1}$ Department of Mathematics Education, Universitas Islam Negeri Sultan Syarif Kasim Riau, Pekanbaru, Indonesia \\ ${ }^{2}$ University of Technology and Applied Sciences, Sohar, Oman \\ ${ }^{3}$ Department of Mathematics, University of Kashmir, India \\ ${ }^{4}$ SRM University, Delhi-NCR, Sonepat, Haryana, India \\ ${ }^{5}$ Department Mathematics and Statistics, Guangxi Normal University, China \\ *Corresponding author: erdawati.nurdin@uin-suska.ac.id | Phone Number: +6281365215530
}

\section{ARTICLE INFO}

Received: 06-12-2020

Received in revised: 23-06-2021

Accepted: 27-09-2021

Available online: 30-10-2021

\section{KEYWORDS}

Cheating;

Covid-19;

Hyperbole;

Mathematics;

Online Assessment;

Open-ended problems;

\section{A B S T R A C T}

The Covid-19 outbreak has an impact on the provision of education. One of them is the process of online assessment or examination. Difficulties occur during online exams; weak supervision can increase cheating behavior among students. Generally, teachers or lecturers think about how to prevent this behavior. However, what if they are allowed to "cheat" on the exam? What do they think? This paper discusses students' perceptions when they were allowed to access various sources during online math exams. What benefits do they get?. The survey was conducted on 78 students of the Mathematics Education Study Program of UIN Sultan Syarif Kasim Riau. The data obtained through a questionnaire were analyzed descriptively. The results of the descriptive analysis showed that the students gave a positive response. The results of this study are expected to be a positive view of the weakness of supervision during online math exams, an idea/way to prevent cheating. In its application, both online learning and assessment, it is necessary to strengthen the character and self-concept of students.

\section{INTRODUCTION}

Indonesia is one of the countries affected by the Covid-19 outbreak. The government's policy to limit physical distance (physical distancing) also impacts the provision of education. Schools and campuses are closed. As a result, learning must take place online. The impact of the Covid-19 outbreak on the dynamics of learning includes (1) schools being shifted to homes through online learning, (2) transforming technology-based learning media, (3) adjusting learning methods, (4) adjusting learning evaluation, and (5) demands collaboration parents as a substitute for teachers at home (Mansyur, 2020).

Evaluation or assessment of learning outcomes is an important and integral component in learning activities (Imania \& Bariah, 2019). Assessment of learning outcomes is part of the learning process, namely a reflection of the understanding of the progress or development of students' thinking abilities. From this assessment process, at least the teacher can know that: (1) learning has been successfully - carried out, (2) the competencies that students must have been learned, and (3) feedback for the teacher to increase learning activities (Winarso, 2018). Currently, the assessment of learning outcomes must be conducted online. However, there are some difficulties or obstacles to implementing online assessments. Online assessments are considered invalid because of the difficulty of monitoring (Prasetyaningtyas, 2020), students commit plagiarism, cooperate while doing assignments, and cheat on exams (Setiadi, 2015). The results of the research by Khodaie et al. (2011) stated that over $90 \%$ of students cheated, $70 \%$ were conducted during exams. Based on the results of the survey, the researchers conducted on Mathematics Education students of UIN Sultan Syarif Kasim Riau, as many as $87 \%$ of students answered that they would cheat on an online exam. Various reasons they expressed include, because of demands to get high scores, lack of understanding and forgetting material or concepts, lack of supervision during - 
exams because another friend cheated, he also cheated, it is considered normal and commonplace and not sure about the answer owned.

According to Diego (2017), the main reasons students cheat are difficult subjects, namely science, mathematics, and English, lack of supervision, and lack of independent learning. Weak supervision during online exams encourages students to cheat and commit plagiarism (Kocdar et al., 2018). Cheating is a problem in online learning (Bedford et al., 2011). They cheat more on online exams (Khan \& Balasubramanian, 2009). Students have many ways of cheating on online exams (Jr et al., 2013). Therefore, educators must identify effective ways of assessing and preventing cheating behavior.

Online assessments inevitably require us to accept the fact that we cannot fully monitor student examinations, and they are likely to cheat. Usually, we (teachers and lecturers) will think and try to prevent this from happening during online exams. However, what if we prevent this cheating behavior by allowing them to cheat? What if students are given access to use various resources during the exam? What do students think about this? I assume that when students are given access to view notes, use calculators, internet sources, and function graphs (Geogebra), it will reduce the level of calculation errors, misuse of equations, and inaccurate graphs. So, they are not only proficient in ordinary mechanical calculations but understand matter deeply and thoroughly. Open exams will provide benefits for students, reduce routine problem work, and provide them the opportunity to comprehend mathematical concepts better (Maciejewski, 2019). Open exams also reduce student tension during exams. Thus, students will feel calmer in answering questions, preventing them from making mistakes because they are anxious and rushed.

Based on these descriptions, in this paper, I try describing how students' perspectives on open exams when they are allowed to access various sources during online math exams. Will students give a positive response to open exams? Will they be more relaxed or worry instead because they think the exam will be more difficult? Will the confusion in calculations be reduced? How do they score learning outcomes? Besides, I describe an overview of open-ended questions as a solution to obtaining credible learning outcome information during online exams.

\section{METHOD}

This study was a descriptive quantitative research, survey research design. In a survey research design, researchers described quantitatively some trends, behaviors, or opinions of a population by examining a sample of that population (Creswell, 2014). Descriptive surveys attempted to reveal situations related to a particular situation topic (Morissan, 2012). This study aimed to describe students' perceptions of the open examination conducted online. The survey design used was a one-shot survey design, which was a one-time study to determine perceptions of current problems (L. Cohen et al., 2007; Lodico et al., 2006). This research was conducted in the Mathematics Education Study Program of UIN Sultan Syarif Kasim Riau, even semester of the 2019/2020 academic year.

The initial target of this research sample was all students who took Analytical Geometry lectures, 88 people. However, the sample in this study amounted to 78 students because 10 students did not return the questionnaire given. This sample size was quite representative. The good sample size for survey research was around 50\% (Gay et al., 2012). Student responses were collected through a questionnaire. The instrument used was an attitude scale that contains closed statements and a questionnaire in the form of open questions. The scale used was the Guttman scale. There are only two answers to this questionnaire, namely "Yes" and "No". This aimed to obtain firm answers from respondents (Sugiyono, 2013). An open questionnaire in the form of a description was intended so that respondents can answer questions according to their wishes based on the situation they were experiencing. Open questionnaires will provide researchers an advantage in obtaining varied data, not only those presented because they have been assumed (Riduwan, 2013). The data obtained from the questionnaire were analyzed by using descriptive statistics, namely frequency and percentage, and deepened with statements from respondents.

\section{RESULTS AND DISCUSSION}

Based on the results of the questionnaire, it was discovered that $87 \%$ of students agreed to the open exam. Students give a positive response to the use of various sources during exams. Similar to the research results, D. Cohen \& Sasson (2016) concluded that $76 \%$ of students chose online quizzes compared to written tests, quizzes were open. Students showed a positive attitude towards the online quiz, and this positive attitude influenced student achievement. However, some students did not like open exams. They argued the questions given on the open exam would be more difficult and took longer to solve. They preferred closed exams to evaluate the learning outcomes achieved.

"Open exams have constraints on the longer time to work on questions." (S27)

"I prefer a closed exam so that I can assess my abilities." (S77)

When completing exam questions, students could use various sources, meaning that the exam was open. Students could employ calculators, function graphs (Geogebra), notes, search for materials on the internet, and asked friends. The questionnaire results provided information that $100 \%$ of students saw notes. Each student used at least two sources, namely notes and a calculator. 


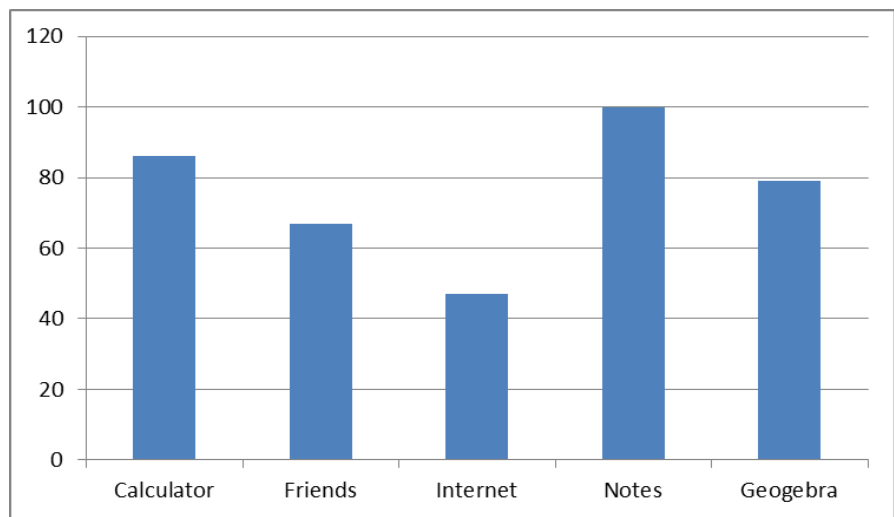

Figure 1. Percentage of references used by students

\section{Number of References Used}

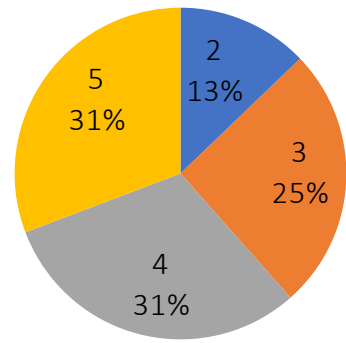

Figure 2. Number of references used by students

Several students mentioned that notes and sources from the internet helped to determine the concepts/equations they should use. The results of this study indicated a low error rate in adopting the equations. Of the 78 students, only 8 were wrong using the equation (see Table 1).

"Open exams make it easier for me to work on questions, when I have to remember difficult concepts and re-check my answers." (S26)

"It assists me with open exams because I can open notes to view concepts or search the internet when I forget the equations I need to adopt to solve the questions." (S13)

More than $80 \%$ of students used calculators during exams. The calculator was employed to prevent miscalculations. The results of this study indicated the use of a calculator reduced inaccuracies in calculations. At least two students made this mistake (see Table 1). The results of research by Walen et al. (2003) states that teachers can allow students to use calculators when accuracy is considered important. Students' anxiety levels decreased, and they became more confident when allowed to use calculators, either during quizzes or exams. Maciejewski (2019) states that the use of various technological aids can help them to verify calculations and prevent technical errors.
Another source utilized by students was Geogebra. Geogebra helped students visualize their understanding and verify the graphic sketches they have drawn. Several studies have shown the use of function graphs, such as Geogebra and Wingeom, makes abstract concepts into concrete (Tatar, 2013), improve representation skills (Fonna \& Mursalin, 2018), assists students to comprehend geometric concepts better (Majerek, 2014; Nurdin et al., 2019; Zulnaidi \& Zamri, 2017), and make them more independent (Saputra \& Fahrizal, 2019).

For more details, the mistakes committed by students were summarized in Table 1.

Table 1. Student error in solving problems

\begin{tabular}{clc}
\hline No & \multicolumn{1}{c}{ Error Type } & Items \\
\hline 1 & Uncomprehend the problem & 8 \\
\hline 2 & Unable to relate to prerequisite material & 16 \\
\hline 3 & Calculation error & 2 \\
\hline 4 & Misuse of concepts & 8 \\
\hline 5 & Incomplete solution & 7 \\
\hline & & Total \\
\hline
\end{tabular}

The mistake that many students commit was not miscalculating or using incorrect concept but lies in not understanding the connection between mathematical concepts, namely hyperbole and transformation geometry (rotation and translation). These two concepts are a prerequisite for solving the questions provided. Hermaini \& Nurdin (2020) state that understanding the prerequisite material is needed to solve problems. However, this error was merely conducted by 16 people or $20.51 \%$. Hence, the possibility of students' low mathematical connection ability cannot be confirmed. Further research is needed.

Thus, access to various sources during exams increased student scores, made them more thorough, able to represent images well, was accustomed to re-examining the results obtained, reduced anxiety during exams, and was more confident with their answers. A total of 60 students believed they would get good grades.

"The flexibility to use various references allows me to check back on the results I get, so I am more confident in my answers. " (S4)

"Open exams help me, who sometimes panic, I can more freely answer questions so that I am sure of my answers." (S12)

"I'm sure I will get a good score on the open exam." (S59)

Furthermore, the feeling of calm facing open examinations did not make students more relaxed. They assume they have to keep preparing for the test. They review the material to be tested so that they can remember the steps to solve the problem and the location of the concept in their notes, so they don't spend time flipping through the notes to recognize the concept they need.

"Even though the exam is open, I still have to study. By studying it makes it easier for me to answer questions without spending a lot of time." (S11) 
"I have to keep repeating and re-understanding the material that has been studied. If not, I will be puzzled to answer the questions. I have to remember where the material is in my notes, and I will have no trouble finding the equation I should use." (S23)

Like the aforementioned, the type of questions given was an open-ended problem. This was intended to obtain credible information about student learning outcomes, namely hyperbole material. Open-ended problems provided opportunities for various answers. This meant that even though they were allowed to ask their friends and look at the notes, they had to use different numbers to obtain different answers from their friends. Thus, they must understand the problems well and use their knowledge to solve the problems given. As stated by Agustini et al. (2017) that the use of open-ended problems in learning geometry can provide students with experience in solving problems and applying their knowledge. In the process of problem-solving, it appeared that students were allowed to comprehend concepts, not just memorizing or just mechanical calculations, using various strategies to solve problems and re-check their answers. Open-ended problems present mathematical content that is explored through problem-solving and reasoning (West, 2018). Open-ended problems provide challenges, invite students to think more, facilitate dynamic investigations to employ various solutions, various representations, decisions, and ways, various strategies in solving problems (Kosyvas, 2015). Open-ended problems stimulate mathematical problem solving (Keh, 2015) and develop creative activities (Aziza et al., 2017; Fatah et al., 2016; Yuniarti et al., 2017).

Thirty seven of the 78 samples obtained perfects scores. This means almost $50 \%$ of students can answer the questions correctly. As said by open-ended problems improving student test scores, increasing mathematics learning achievement (Afandi, 2018; Koriyah \& Harta, 2015). By providing open-ended questions, students are allowed to use their thinking abilities and skills. This activity assists student improves their understanding and communicates that understanding. This confirms the results of the research of Rodriguez \& Bonner (2018); Viseu \& Oliveira (2012) stated that open-ended problems increase communication, both between students and with their teachers.

The results of this study also demonstrated that although the questions provided were more complicated than usual, they were calmer and motivated to solve the problems well. (Kress, 2018) states that with open-ended problems, students will get used to and more comfortable working on complex problems. Students are encountered with a variety of answers when solving open-ended problems (Bahar \& Maker, 2015). They realize the problem given has many solutions, so they are more confident in their answers. Open-ended problems do not depend on one accurate answer. This increases students' confidence to solve them(Koriyah \& Harta, 2015; Wu, 2020).

"Open-ended questions spurred me to think, look for and solve problems with various sources to solve the problems given." (S32)

"The questions are more challenging, but I can do it more relaxed." (S10)

I know, not all teachers agree with this, but I believe this paper can provide a positive perspective on the current situation, which requires us to carry out online assessments. With all the difficulties, however, there is consistently a lesson that can be taken for every situation. One of them is to provide opportunities for lecturers or teachers to improve their competence in conducting assessments, especially getting used to formulating more conceptual questions, open-ended problems, not routine.

In closing, although it has many advantages, open exams also demonstrate weaknesses, including: (1) Some students said they did not have to study before the exams because they could see the notes during the exam. This means that open exams offer the potential to make students lazier so that they become puzzled during exams and eventually run out of time to resolve the questions. However, this definitely returns to their self-concept and the goals they want to achieve; (2) too dependent on technology, for example, calculators, instead of causing them to become dependent. Therefore, control is needed in its use. For example, low-level students should avoid employing calculators because they have to master mechanical calculations. They must instill the concept that calculators, function graphs, or other technologies are merely tools. They must be able to distinguish skills from understanding.

\section{CONCLUSION}

The Covid-19 outbreak has also had an impact on the world of education. The learning and assessment process must be done online. Lack of supervision during online assessments demonstrates the potential to increase cheating behavior. Of course, this behavior must be prevented. What if this behavior was prevented by allowing them to cheat? Allow them access to multiple resources during online math exams? In that sense, the exam is open. The survey was conducted on 78 students through a questionnaire. As many as $87 \%$ of students offered positive responses to open exams. The results showed that open exams provided many benefits for students. Among them: (1) reducing the level of calculation error (2) preventing mistaken use of concepts (3) being more careful when sketching graphs (4) improving learning outcomes (5) being more confident about the results they get, the most important (6) students do not cheat, because they are allowed to use various sources during the exam, and finally (7) the questions given 
are in the form of open-ended problems. Open-ended problems have many advantages, including increasing the ability to comprehend, communicate, reason, creativity, and solve mathematical problems. This is also an opportunity for us as teachers or lecturers to improve our competence in conducting assessments. However, the results of this study represent a positive point of view on the online exams that we should do at this time. An idea/way to prevent cheating behavior, although other ways can be used. In its application, students' character and self-concept need to be strengthened.

\section{REFERENCES}

Afandi, A. (2018). Difference of learning mathematics between open question model and conventional model. Malikussaleh Journal of Mathematics Learning, 1(1), 13-18. https://doi.org/https://doi.org/10.29103/mjml.v1i1.620

Agustini, R. Y., Suryadi, D., \& Jupri, A. (2017). Construction of open-ended problems for assessing elementary student mathematical connection ability on plane geometry. Journal of Physics: Conference Series, 895, 1-8. https://doi.org/10.1088/1742-6596/895/1/012148

Aziza, M., House, S., Ave, T., Bristol, T. H., Citation, U. K. S., \& Tezer, M. (2017). The use of open-ended question pictures in the mathematics classroom. New Trends and Issues Proceedings on Humanities, 4(9), 1-9. DOI: https://doi.org/10.18844/prosoc.v4i9.3036

Bahar, A., \& Maker, C. J. (2015). Cognitive backgrounds of problem solving: a comparison of open-ended vs .closed mathematics problems. Eurasia Journal of Mathematics, 11(6), 1531-1546. https://doi.org/10.12973/eurasia.2015.1410a

Bedford, D. W., Gregg, J. R., \& Clinton, M. S. (2011). Preventing online cheating with technology: a pilot study of remote proctor and an update of its use. Journal of Higher Education Theory and Practice, 11(2), 41-58. http://www.na-businesspress.com/JHETP/bedford_abstract.html

Cohen, D., \& Sasson, I. (2016). Online quizzes in virtual learning environment as a tool for formative assessment. Journal of Technology and Science Education, 6(3), 188-208. https://doi.org/10.3926/jotse.217

Cohen, L., Manion, L., \& Morrison, K. (2007). Research methods in education (Sixth Ed). Routledge.

Creswell, J. W. (2014). Research design: qualitative, quantitative and mixed methods approaches (Fourth Ed). Sage Publication.

Diego, L. A. B. . (2017). Friends with benefits: causes and effects of learners ' cheating practices during examination. IAFOR Journal of Education, 5(2), 121-138. https://eric.ed.gov/?id=EJ1156266

Fatah, A., Suryadi, D., Sabandar, J., \& Turmudi. (2016). Open-ended approach: an effort in cultivating students' mathematical creative thinking ability and self-esteem in mathematics. Journal on Mathematics Education, 7(1), 9-18. https://eric.ed.gov/?id=EJ1096314
Fonna, M., \& Mursalin. (2018). Using of Wingeom software in geometry learning to improving the of mathematical representation ability. Malikussaleh Journal of Mathematics Learning, 1(2), 40-43. DOI: https://doi.org/10.29103/mjml.v1i2.1174

Gay, L. R., Mills, G. E., \& Airasian, P. W. (2012). Educational research: competencies for analysis and applications (Tenth Ed). Pearson Education.

Hermaini, J., \& Nurdin, E. (2020). Bagaimana kemampuan pemecahan masalah matematis siswa dari perspektif minat belajar? JURING (Journal for Research in Mathematics Learning), 3(2), 141-148. https://doi.org/10.24014/juring.v3i1.9597

Imania, K. A. N., \& Bariah, S. K. (2019). Rancangan pengembangan instrumen penilaian pembelajaran berbasis daring. Jurnal PETIK, 5, 31-47. https://doi.org/10.31980/jpetik.v5i1.445

Jr, J. M., Fitterer, A., Brazier, E., Leonard, J., \& Brown, A. (2013). Examining online college cyber cheating methods and prevention measures. The Electronic Journal of E-Learning, 11(2), 139-146.

Keh, L. K. (2015). Preliminary Study of Creative Problem Solving on Open-ended Mathematical Problems. 2(2).

Khan, Z. R., \& Balasubramanian, S. (2009). Students go click , flick and cheat: e-cheating, technologies and more. Journal of Academic and Business Ethics, 1-26.

Khodaie, E., Moghadamzadeh, A., \& Salehi, K. (2011). Factors affecting the probability of academic cheating school students in Tehran. Procedia - Social and Behavioral Sciences, 29, 1587-1595.

https://doi.org/10.1016/j.sbspro.2011.11.401

Kocdar, S., Karadeniz, A., Peytcheva-Forsyth, R., \& Stoeva, V. (2018). Cheating and plagiarism in e-assessment: students' perspectives. Open Praxis, 10(3), 221-235. https://doi.org/10.5944/openpraxis.10.3.873

Koriyah, V. N., \& Harta, I. (2015). Pengaruh open-Eeded terhadap prestasi belajar, berpikir kritis dan kepercayaan diri siswa SMP. Pythagoras: Jurnal Pendidikan Matematika, 10(1), 95105.

Kosyvas, G. (2015). International Journal of Mathematical Levels of arithmetic reasoning in solving an open-ended problem. August. https://doi.org/10.1080/0020739X.2015.1072880

Kress, N. E. (2018). 6 Essential questions for problem solving. The Mathematics Teacher, 111(3), 190-196.

Lodico, M. G., Spaulding, D. T., \& Voegtle, K. H. (2006). Methods in educational research: from theory to practice. John Wiley \& Sons.

Maciejewski, W. (2019). Let your students cheat on exams. PRIMUS, 1-16. https://doi.org/10.1080/10511970.2019.1705450

Majerek, D. (2014). Application of geogebra for teaching mathematics. Advances in Science and Technology Research Journal, 8(24), 51-54. https://doi.org/10.12913/22998624/567

Mansyur, A. R. (2020). Dampak COVID-19 terhadap dinamika pembelajaran di Indonesia. Education and Learning 
Journal, 1(2), 113-123.

https://doi.org/10.33096/eljour.v1i2.55

Morissan. (2012). Metode penelitian survei. Kencana Prenadamedia Group.

Nurdin, E., Ma'aruf, A., Amir, Z., Risnawati, R., Noviarni, N., \& Azmi, M. P. (2019). Pemanfaatan video pembelajaran berbasis Geogebra untuk meningkatkan kemampuan pemahaman konsep matematis siswa SMK. Jurnal Riset Pendidikan Matematika, 6(1), 87-98. https://doi.org/10.21831/jrpm.v6i1.18421

Prasetyaningtyas, S. (2020). Pelaksanaan belajar di rumah (BDR) secara online selama darurat covid-19 di SMP N 1 Semin. Ideguru: Jurnal Karya Ilmiah Guru, 5(1), 86-94.

Riduwan. (2013). Belajar mudah penelitian untuk guru, karyawan dan peneliti pemula. Alfabeta.

Rodriguez, C., \& Bonner, E. P. (2018). The impact of teacher questioning and open-ended problems on mathematical communication. The Journal of Teacher Action Research, 4(3), 68-89.

Saputra, E., \& Fahrizal, E. (2019). The development of mathematics teaching materials through Geogebra software to improve learning independence. Malikussaleh Journal of Mathematics Learning, 2(2), 39-44. https://doi.org/https://doi.org/10.29103/mjml.v2i2.1860

Setiadi, A. (2015). Pelanggaran etika pendidikan pada sistem pembelajaran e-learning. Cakrawala-Jurnal Humaniora, 15(2), 1-9. https://doi.org/10.3124/jc.v15i2.4896

Sugiyono. (2013). Penelitian pendidikan: pendekatan kuantitatif dan kualitatif dan r\&d. Alfabeta.

Tatar, E. (2013). The effect of dynamic software on prospective mathematics teachers' perceptions regarding information and communication technology. Australian Journal of Teacher Education, 38(12), 1-16.
Viseu, F., \& Oliveira, I. B. (2012). Open-ended tasks in the promotion of classroom communication in mathematics. International Electronic Journal of Elementary Education, 4(2), 287-300.

Walen, S. B., Williams, S. R., \& Garner, B. E. (2003). Pre-service teachers learning mathematics using calculators: a failure to connect current and future practice. 19, 445-462. https://doi.org/10.1016/S0742-051X(03)00028-3

West, J. (2018). Stimulating mathematical reasoning with simple open-ended tasks. 23(1), 37-40.

Winarso, W. (2018). Authentic assessment for academic performance : study on the attitudes, skills , and knowledge of grade 8 mathematics students. Malikussaleh Journal of Mathematics Learning, 1(1), 1-8. https://doi.org/https://doi.org/10.29103/mjml.v1i1.579

$\mathrm{Wu}, \mathrm{H}$. (2020). The role of open-ended problems in mathematics education. Journal of Mathematical Behavior, 58(June 2000). https://doi.org/10.1016/0732-3123(94)90044-2

Yuniarti, Y., Kusumah, Y. S., Suryadi, D., \& Bana, G. (2017). The effectiveness of open-ended problems based analyticsynthetic learning on the mathematical creative thinking ability of pre-service elementary school teachers. International Electronic Journal of Mathematics Education, 12(3), 655-666.

Zulnaidi, H., \& Zamri, sharifah N. A. S. (2017). The effectiveness of the GeoGebra software: the intermediary role of procedural knowledge nn students' conceptual knowledge and their achievement in mathematics. Eurasia Journal of Mathematics, 13(6), 2155-2180.

https://doi.org/10.12973/eurasia.2017.01219a 